\title{
The effects of early menarche on sexual and reproductive health: A scoping review
}

\author{
Hanny Wulandari ${ }^{1 *}$, Dwi Ernawati ${ }^{2}$, Sri Lestari ${ }^{3}$ \\ 1,2,3 Universitas Aisyiyah, Ringroad Barat 63 Nogotirto Gamping Sleman 55292, Yogyakarta, Indonesia \\ ${ }^{1}$ Hannywulandari11@gmail.com*, ${ }^{2}$ dwiernawati09@gmail.com, ${ }^{3}$ tari.unisa@gmail.com \\ *corresponding author
}

Submission date: 22 Maret 2021, Receiptdate: 5 April 2021, Publicationdate: 1 Juli 2021

\begin{abstract}
The aim of this scoping review is to interpret the effects of early menarche on sexual and reproductive health. The Scoping Review method was carried out using the following steps; 1) identifying research questions; 2) identifying relevant studies, through the Pubmed, Ebsco, and Wiley databases. The article criteria used are articles published from 2009 to 2019 and discussing the effects of early menarche on sexual and reproductive health; 3) the selection of articles was described using the Prisma Flow Chart where in full text search results, 18 articles were obtained and 9 articles was used for the review as these have quality assessment and according to population, methods, and results; 4) carrying out data charting; and 5) carrying out the compilation of results reports. Early menarche and high sexual desire are health problems that have serious implications for adolescents. Provision of appropriate information and education on sexual and reproductive health for adolescents is urgently needed. It is hoped that the findings from the articles that have been reviewed can contribute to the importance of providing sex education from an early age.
\end{abstract}

Keywords: early menarche, sexual health, reproductive health

\section{INTRODCUTION}

Menstruation that is experienced by women for the first time is called menarche. Physically, menarche is characterized by bleeding from the vagina due to shedding of the endometrial lining (Kusmiran, 2014). Menarche age varies in woman, from 10-16 years old. The age of menarche is said to be normal if it occurs at the age of 12-14 years, so that adolescents who experience age-aged $<12$ years are said to be early menarche (Susanti, 2012).

Research conducted in Brazil in 2012 found that young women who experienced early menarche had a percentage of $79.8 \%$, while normal menarche was $20.2 \%$ (Araujo et al, 2016). Another study conducted in Columbia in 2017 showed that adolescents who experienced premature menarche at the age of $<10$ years and 11 years respectively were 450 adolescents $(9.2 \%)$ and 932 adolescents (18.2\%) (Platt et al, 2017). 
Through their research suggest that in a descriptive study, the age of menarche in young women in Indonesia in 2013 has decreased compared to the previous year. On average, Indonesian girls experience menarche in the age range of 9-15 years. The results of the study in Bandung showed that $37.4 \%$ of adolescents experienced menarche at the age $<12$ years and $3.7 \%$ of adolescents experienced menarche at aged $>12$ years (Ganabathy et al, 2016). Research conducted (Darmayitasari, 2017) in Yogyakarta City found that adolescents who experience premature menarche at the age of $<12$ years are $68.9 \%$.

The shift from the age of menarche to a younger age puts young women at risk of developing breast cancer, delayed menopause, risk of emotional stress, risk of gestational diabetes and risk of heart disease. Early menarche in young women causes them to come into contact with sexual life more quickly, resulting in an increased incidence of unintended pregnancies, adolescent childbirth, and increased abortion in adolescents (Fildza et al, 2014).

Decreased age at menarche, menstrual problems, and the poor reproductive health status of the adolescent girls in this study have made menstrual problems and contraceptive adherence important aspects of adolescent health care, especially when appropriate sources of reproductive health information are not fully utilized. Therefore, there is a need to build youth-friendly clinics, including sexuality education in school curricula in these neighborhoods (Ajah et al., 2015)

The purpose of this Scoping Review is to interpret the effects of early menarche on sexual and reproductive health. This is considering that the rate of early menarche in Indonesia is starting to increase and the knowledge of parents and school teachers is lacking in providing education about the importance of sexual and reproductive health in adolescents. Through this Scoping Review, which presents the effects of early menarche on sexual and reproductive health, based on research findings that have been conducted by previous researchers in various parts of the world, it is hoped that it can contribute to increasing awareness of related parties about the importance of sex education for adolescents. It is hoped that parents, schools and health workers can work together effectively in providing education to their children.

\section{RESEARCH METHODS}

Scoping review is a systematic review used to interpret evidence-based results and map the concepts underlying the research area, sources of evidence, and types of evidence available (Tricco et al., 2016). The preparation of a scoping review adapts the framework (Arksey \& O'Malley, 2005) which consists of five stages of preparation. This stage starts from the stage of identifying scoping review questions, identifying relevant articles by creating a research framework, selecting a database that will be used to search literature and explaining the search strategy, conducting literature selection / selection, conducting data charting by making data extraction and assessing the quality of the articles (critical appraisal) and the last stage is the data collection stage and the mapping of the scoping review theme. The stages regarding the preparation of a scoping review regarding the effects of early menarche on sexual and reproductive health are described as follows. 


\section{Step 1: Identifying the scoping review questions}

The framework used is PEOs (Population, Exposure, Outcomes). Research question: What is the effect of early menarche on sexual and reproductive health?

Table 1. Framework research question

\begin{tabular}{|c|c|c|}
\hline $\mathrm{P}$ & E & Os \\
\hline Teenage girl & $\begin{array}{l}\text { Experiencing early } \\
\text { menarche }\end{array}$ & $\begin{array}{l}\text { The effects of early menarche on sexual } \\
\text { and reproductive health }\end{array}$ \\
\hline
\end{tabular}

\section{Step 2: Identify Relevant Articles}

The stage after identifying the scoping review question is identifying the relevant articles. This is done by specifying a key parameter, as follows:

Table 2. Article Criteria

\begin{tabular}{ll}
\hline \multicolumn{1}{c}{ Inclusion Criteria } & \multicolumn{1}{c}{ Exclusion Criteria } \\
\hline Original article & Opinion articles \\
Articles in English & Book Review \\
Articles published from 2009 to 2019 & The opinion of health workers \\
Primary / secondary research & Review articles \\
Discuss early menarche experiences & \\
Relates to the effects of early menarche & \\
\hline
\end{tabular}

Article searches were performed using three databases (Pubmed, Ebsco Wiley) and Google Scholar's Gray Literature. The keywords used in the search were Effect OR Outcomes AND Menarche OR Menstruation OR Menstrua * OR menses OR "Early Menarche" AND "Reproductive Health" OR sexual reproduction * AND sexual behavior * OR "sexual debut" OR "Sexual PartnersOR" unsafe sex " OR "unprotected sex".

Search is limited to papers published in the last 2009-2019 so that the results displayed in the article are the latest results, use English, there are no specific country criteria to target and are not limited to the type of article.

\section{Step 3: Selection or Selection of Articles}

From the search results on 3 databases and reference lists, there were 116 articles which were then filtered based on titles / abstracts related to early menarche on sexual and reproductive health so that 111 articles were obtained. This 111 articles was rescreened to obtain articles that correspond to the effects of early menarche on sexual and reproductive health. A full text search of 73 identified articles was carried out to filter the content of the articles. From the results of filtering the content of the articles, the suitability of the population and the results, as well as the critical appraisal, 9 articles were used for the Scoping Review. 


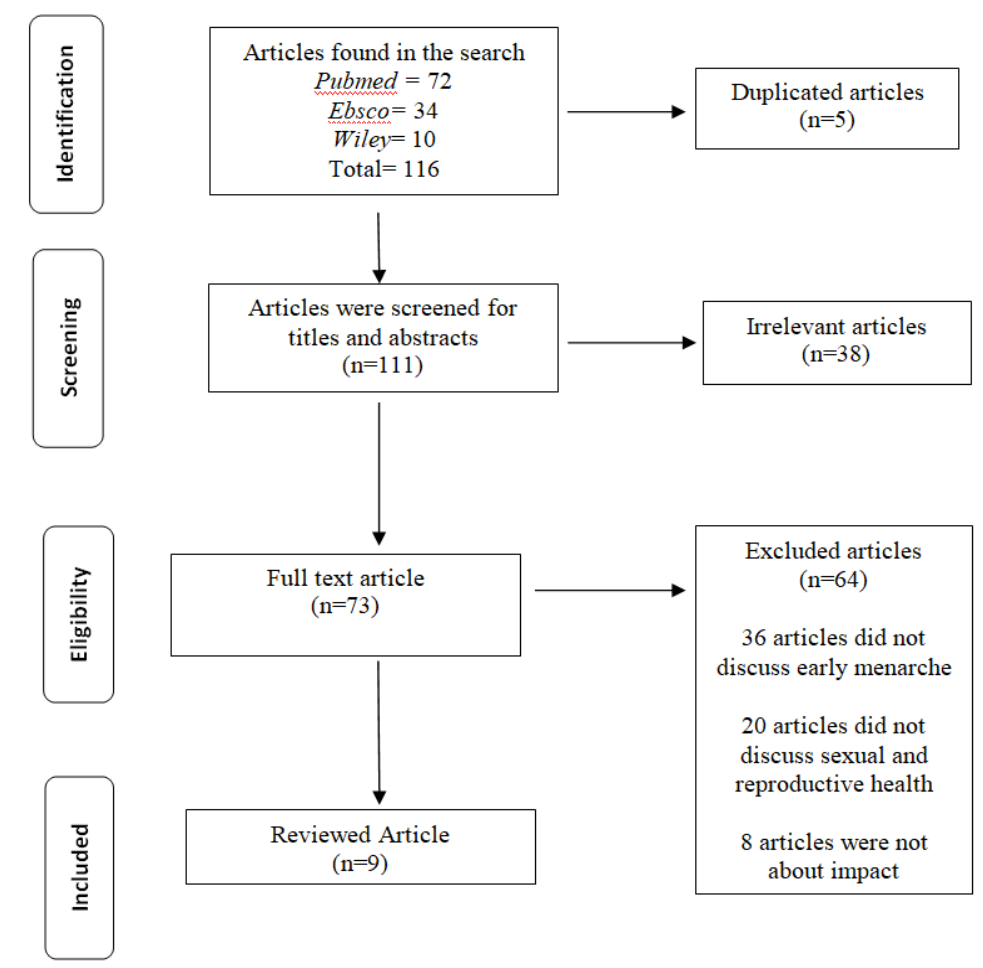

Figure 1. Prisma Flowchart

\section{Step 4: Charting Data}

The nine articles were obtained by including key criteria such as study location, study population, research objectives, methodology, and significant findings or recommendations. The authors independently recorded the information and then compared the charted data.

Critical appraisal is used to assess the quality of the articles used. The tool chosen to assess the quality of articles is the Joana Brigs checklist from the Joana Brigs Institute. At the critical appraisal stage, there are 9 articles that match the topic of early menarche. Most of the articles on the research method or as many as 5 articles using the Cross Sectional and 4 articles using the Cohort method.

Each research method has a different critical appraisal checklist. After the critical appraisal was carried out, 5 grade A articles and 1 grade B articles were obtained. All articles were deemed eligible for review by the author. 
Table 3. Charting Data

\begin{tabular}{|c|c|c|c|c|c|c|}
\hline Code & $\begin{array}{l}\text { Title / author / } \\
\text { year / grade }\end{array}$ & Country & Objectives & Method & $\begin{array}{l}\text { Participant } \\
\mathrm{s} / \text { number } \\
\text { of samples }\end{array}$ & Findings \\
\hline A1 & $\begin{array}{l}\text { Earlier } \\
\text { menarche is } \\
\text { associated with a } \\
\text { higher } \\
\text { prevalence of } \\
\text { Herpes simplex } \\
\text { type-2 (HSV-2) } \\
\text { in young women } \\
\text { in rural } \\
\text { Malawi.(Glynn, } \\
\text { Kayuni, } \\
\text { Gondwe, Price, } \\
\text { \& Crampin, } \\
\text { 2014). Q1 }\end{array}$ & Malawi & $\begin{array}{l}\text { To determine the } \\
\text { correlation } \\
\text { between age at } \\
\text { menarche and } \\
\text { sexually } \\
\text { transmitted } \\
\text { infections. }\end{array}$ & $\begin{array}{l}\text { Cross } \\
\text { Sectional }\end{array}$ & $\begin{array}{l}3,965 \\
\text { women } \\
\text { aged 15-30 }\end{array}$ & $\begin{array}{l}\text { Women aged } \\
<14 \text { who had } \\
\text { menarche and } \\
\text { experienced } \\
\text { sexual debut in } \\
\text { a previous } \\
\text { marriage were } \\
\text { more likely to } \\
\text { experience } \\
\text { positive Herpes } \\
\text { simplex type-2 } \\
\text { (HSV-2) } \\
\text { compared with } \\
\text { those who had } \\
\text { menarche aged } \\
14,15,16\end{array}$ \\
\hline $\mathrm{A} 2$ & $\begin{array}{l}\text { Age at } \\
\text { Menarche, } \\
\text { Schooling, and } \\
\text { Sexual Debut in } \\
\text { Northern } \\
\text { Malawi(Glynn et } \\
\text { al., 2010). Q1 }\end{array}$ & Malawi & $\begin{array}{l}\text { To find out } \\
\text { trends } \\
\text { situations and } \\
\text { sexual debut in } \\
\text { relation to school } \\
\text { education and } \\
\text { age } \\
\text { menarche.. }\end{array}$ & $\begin{array}{l}\text { Cross } \\
\text { Sectional }\end{array}$ & $\begin{array}{l}6796 \\
\text { women and } \\
5253 \text { men } \\
\text { aged } 15-59\end{array}$ & $\begin{array}{l}\text { Women with } \\
\text { early sexual } \\
\text { debut at the age } \\
\text { of } 16 \text { tend to } \\
\text { experience } \\
\text { menarche at the } \\
\text { age of under } 14 \\
\text { years. Women } \\
\text { with early } \\
\text { menstruation } \\
\text { and acquaintance } \\
\text { with sex and } \\
\text { early marriage, } \\
\text { tend to lead to } \\
\text { drop out of } \\
\text { school. }\end{array}$ \\
\hline A3 & $\begin{array}{l}\text { Adolescent } \\
\text { reproductive } \\
\text { health } \\
\text { challenges } \\
\text { among } \\
\text { schoolgirls in } \\
\text { southeast } \\
\text { Nigeria: role of } \\
\text { knowledge of } \\
\text { menstrual } \\
\text { pattern and } \\
\text { contraceptive } \\
\text { adherence. (Ajah } \\
\text { et al., 2015). Q1 }\end{array}$ & Nigeria & $\begin{array}{l}\text { to determine age } \\
\text { at menarche, } \\
\text { menstrual } \\
\text { patterns, and } \\
\text { awareness and } \\
\text { use of modern } \\
\text { contraception } \\
\text { among middle } \\
\text { school girls in } \\
\text { Abakaliki, } \\
\text { Nigeria }\end{array}$ & $\begin{array}{l}\text { Cross } \\
\text { Sectional }\end{array}$ & $\begin{array}{l}482 \\
\text { teenage } \\
\text { girls in } \\
\text { middle } \\
\text { school }\end{array}$ & $\begin{array}{l}\text { The mean age } \\
\text { for menarche is } \\
\text { under } 13 \text { years. } \\
\text { A total of } 101 \\
(21 \%) \text { of the } \\
\text { students were } \\
\text { sexually active. } \\
\text { Although } 365 \\
\text { ( } 75.7 \%) \text { of the } \\
\text { students were } \\
\text { aware of } \\
\text { modern } \\
\text { contraception, } \\
\text { only } \\
\text { (18.5\%) of } \\
\text { them were } \\
\text { aware of } \\
\text { emergency } \\
\text { contraception } \\
\text { and } 43 \text { (8.9\%) }\end{array}$ \\
\hline
\end{tabular}




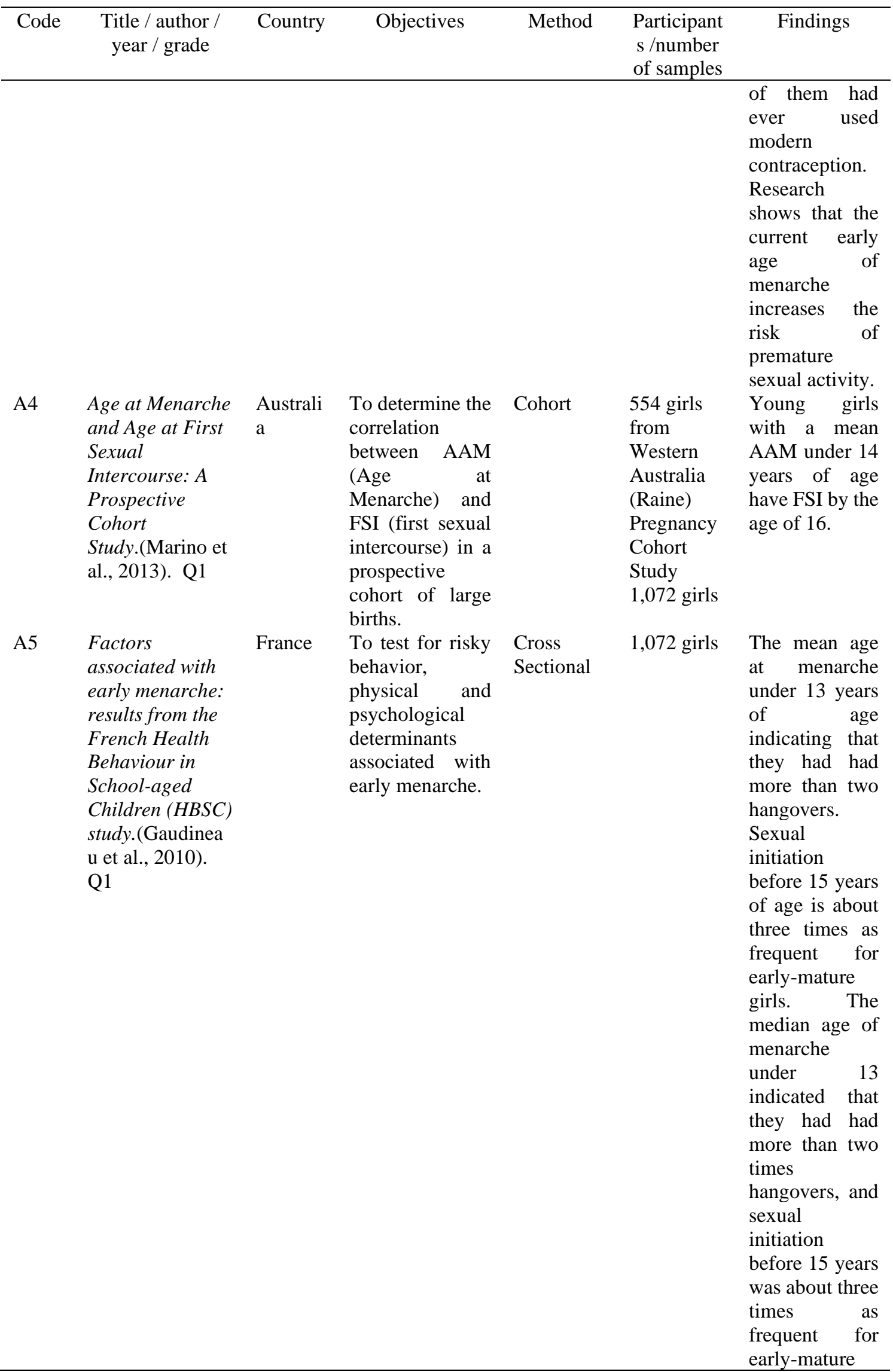




\begin{tabular}{|c|c|c|c|c|c|c|}
\hline Code & $\begin{array}{l}\text { Title / author / } \\
\text { year / grade }\end{array}$ & Country & Objectives & Method & $\begin{array}{l}\text { Participant } \\
\mathrm{s} / \text { number } \\
\text { of samples }\end{array}$ & Findings \\
\hline A6 & $\begin{array}{l}\text { The } \\
\text { Development of } \\
\text { Reproductive } \\
\text { Strategy in } \\
\text { Females: Early } \\
\text { Maternal } \\
\text { Harshness } \\
\text {,Earlier } \\
\text { Menarche, } \\
\text { Increased Sexual } \\
\text { Risk } \\
\text { Taking.(Belsky } \\
\text { et al., 2010). Q1 }\end{array}$ & $\begin{array}{l}\text { United } \\
\text { States }\end{array}$ & $\begin{array}{l}\text { To examine } \\
\text { family } \\
\text { propositions in } \\
\text { the NICHD } \\
\text { Early Child Care } \\
\text { and Youth } \\
\text { Development } \\
\text { Study in the } \\
\text { socialization of } \\
\text { puberty } \\
\text { maturation plays } \\
\text { a role in linking } \\
\text { and magnifying } \\
\text { adolescent } \\
\text { experiences of } \\
\text { sexual risk (i.e. } \\
\text { frequency of } \\
\text { sexual behavior) } \\
\text { and, other risk } \\
\text { taking (e.g., } \\
\text { alcohol, drugs, } \\
\text { delinquency }\end{array}$ & Cohort & $\begin{array}{l}1,364 \\
\text { children }\end{array}$ & $\begin{array}{l}\text { girls compared } \\
\text { to others. } \\
\text { The initial age } \\
\text { of menarche is } \\
\text { under } 14 \text { years, } \\
\text { which leads to } \\
\text { sex with a } \\
\text { greater risk. }\end{array}$ \\
\hline A7 & $\begin{array}{l}\text { Early pubertal } \\
\text { onset and its } \\
\text { relationship with } \\
\text { sexual risk } \\
\text { taking, substance } \\
\text { use and anti- } \\
\text { social } \\
\text { behaviour: a } \\
\text { preliminary } \\
\text { cross-sectional } \\
\text { study. (Downing } \\
\text { \& Bellis, 2009). } \\
\text { Q1 }\end{array}$ & England & $\begin{array}{l}\text { to determine the } \\
\text { relationship } \\
\text { between the } \\
\text { onset of puberty } \\
\text { and sexual risk } \\
\text { taking, drug use } \\
\text { and anti-social } \\
\text { behavior }\end{array}$ & $\begin{array}{l}\text { Cross } \\
\text { Sectional }\end{array}$ & $\begin{array}{l}2093 \\
\text { children }\end{array}$ & $\begin{array}{l}\text { Overall, } 45.6 \% \\
\text { of women } \\
\text { reported } \\
\text { menarche } \leq 12 \\
\text { years. puberty } \\
\text { earlier and } \\
\text { predicted } \\
\text { drinking } \\
\text { alcohol, } \\
\text { smoking and } \\
\text { drugs when } \\
\text { they were }<14 \\
\text { years old and } \\
\text { had sexual } \\
\text { debut and } \\
\text { unprotected sex } \\
\text { at }<16 \text { years of } \\
\text { age. }\end{array}$ \\
\hline A8 & $\begin{array}{l}\text { Early Menarche } \\
\text { and Internalizing } \\
\text { and } \\
\text { Externalizing in } \\
\text { Adulthood: } \\
\text { Explaining the } \\
\text { Persistence of } \\
\text { Effects. (Mendle } \\
\text { et al., 2019). Q1 }\end{array}$ & $\begin{array}{l}\text { New } \\
\text { York }\end{array}$ & $\begin{array}{l}\text { To find out the } \\
\text { previous age at } \\
\text { menarche is } \\
\text { associated with } \\
\text { an increase in } \\
\text { internalization } \\
\text { and } \\
\text { externalization } \\
\text { that persists into } \\
\text { adulthood }\end{array}$ & Cohort & $\begin{array}{l}10,480 \\
\text { women }\end{array}$ & $\begin{array}{l}\text { Found that } \\
\text { early menarche } \\
\text { is associated } \\
\text { with a greater } \\
\text { degree of } \\
\text { postmenarchea } \\
\text { l education, } \\
\text { physical and } \\
\text { sexual } \\
\text { violence, } \\
\text { teenage } \\
\text { pregnancy, } \\
\text { physical }\end{array}$ \\
\hline
\end{tabular}




\begin{tabular}{|c|c|c|c|c|c|c|}
\hline Code & $\begin{array}{l}\text { Title / author / } \\
\text { year / grade }\end{array}$ & Country & Objectives & Method & $\begin{array}{l}\text { Participant } \\
\mathrm{s} / \text { number } \\
\text { of samples }\end{array}$ & Findings \\
\hline A9 & $\begin{array}{l}\text { Age At Menarche } \\
\text { And Sexual } \\
\text { Debut Among } \\
\text { Young Filipino } \\
\text { Women. (Tey et } \\
\text { al., 2019) }\end{array}$ & (1) & $\begin{array}{l}\text { to find out the } \\
\text { correlation } \\
\text { between trends } \\
\text { and differences } \\
\text { in age at } \\
\text { menarche and } \\
\text { age at sexual } \\
\text { debut in various } \\
\text { sub-groups of } \\
\text { the Philippine } \\
\text { population and } \\
\text { to determine the } \\
\text { biosocial factors } \\
\text { associated with } \\
\text { the timing of } \\
\text { sexual debut. }\end{array}$ & Cohort & $\begin{array}{l}5200 \\
\text { women }\end{array}$ & $\begin{array}{l}\text { assault, and } \\
\text { sexual } \\
\text { mediated } \\
\text { assault } \\
\text { associations. } \\
\text { Early puberty } \\
\text { in girls is } \\
\text { associated with } \\
\text { psychological } \\
\text { prolongation } \\
\text { where the } \\
\text { problems are } \\
\text { found not only } \\
\text { during } \\
\text { adolescence, } \\
\text { but also in } \\
\text { adulthood. } \\
\text { The mean and } \\
\text { median ages of } \\
\text { menarche were } \\
13.2 \text { years and } \\
12.6 \text { years. } \\
\text { Sexual debut at } \\
19.6 \text { years. } \\
\text { Sexual debut } \\
\text { during } \\
\text { adolescence } \\
\text { varies across } \\
\text { ethnic groups. } \\
\text { However, in a } \\
\text { rather small } \\
\text { urban area, } \\
\text { when } \\
\text { compared with } \\
\text { the } \\
\text { differential, the } \\
\text { proportion who } \\
\text { have had their } \\
\text { first sex are } \\
\text { those aged } 15 \\
\text { years compared } \\
\text { with urban } \\
\text { women who } \\
\text { are } 17 \text { years } \\
\text { old. }\end{array}$ \\
\hline
\end{tabular}

\section{Step 5: Data Collection and Mapping}

The process of extracting data from 9 articles that were suitable and of good quality was then carried out at this stage. This process aims to find out in detail and classify several points from the article, such as the country of the study, the objectives of the study, the methods used, and the results or findings of the study. Of the 9 selected articles, 5 articles were found using the Cross Sectional research method and 4 articles using the Cohort method. 


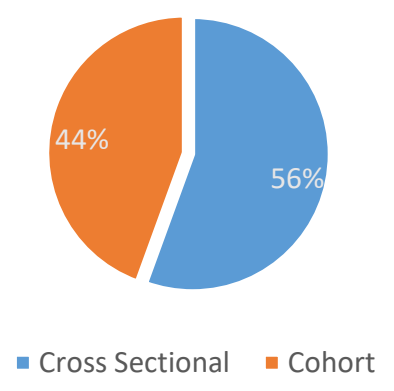

Figure 2. Characteristics Design Study

The majority of articles obtained come from developed and developing countries. The details were 4 articles from developing countries (Nigeria, Malawi, Philippines) and 5 articles from developed countries (France, United States, New York, UK, Australia)

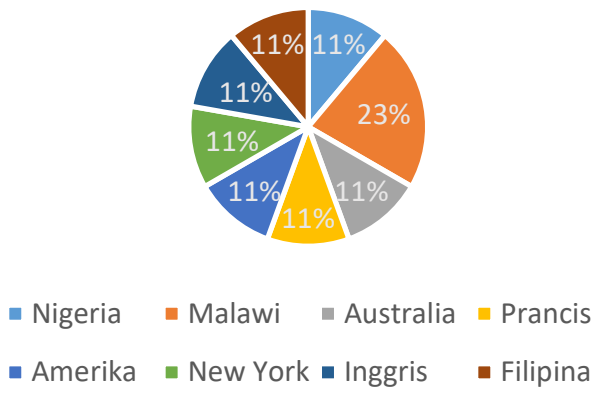

Figure 3. Characteristics Country

The authors classify the effects of early menarche on sexual and reproductive health into 3 main points, namely problems of sexual and reproductive health, diseases of sexual and reproductive health and factors that affect sexual and reproductive health.

\section{RESULTS AND DISCUSSION}

\section{RESULTS}

There were 3 themes from 9 articles that were obtained, namely sexual and reproductive health problems, diseases in sexual and reproductive health and the factors that influence them.

\section{Sexual and Reproductive Health Problems}

a. Early Sex

The results of research conducted by (Ajah et al., 2015) found that the average age of menarche was under 13 years. A total of 101 students $(21 \%)$ were active in sexual intercourse. Although $365(75.7 \%)$ of the students were aware of modern contraception, only $89(18.5 \%)$ of them were aware of emergency contraception and $43(8.9 \%)$ of them had ever used modern contraception. Research shows that nowadays, early menarche increases the risk of premature sexual activity.

b. The Low Use of Contraception

Mother was the main source of information on menstruation in $81.5 \%$ of respondents. Only eight (18.6\%) out of 43 respondents who had ever used modern contraception were adherent to modern contraception. Their main sources of information on modern contraception are friends (58.9\%) and the mass media 
(51\%). Only $15(16.9 \%)$ of 89 students were aware of emergency contraception and had used it. The majority of emergency-contraceptives used were oral contraceptive pills (Ajah et al., 2015).

\section{Diseases of Sexual and Reproductive Health}

a. Herpes simplex type-2 (HSV-2)

Women who experienced menarche at age $<14$ and had sexual debut were more often Herpes simplex type-2 (HSV-2) positive compared with those who had menarche at age 14,15,16. Age at sexual debut and age at marriage increases with age at menarche (Glynn et al., 2014)

b. HIV

Overall it was found that $25.5 \%$ of those tested were HSV-2 positive and $5.6 \%$ were HIV positive (Glynn et al., 2014).

\section{Factors Affecting Sexual and Reproductive Health}

a. Education

Dysmenorrhea occurred in $64.1 \%$ of the respondents from this study and less than $72 \%$ and $74.4 \%$ in Nigeria and Ghana. However, this compares with the $65 \%$ reported in the United States for premenstrual syndrome, which occurs in $75.1 \%$ of respondents and less than $85.5 \%$ reported in Calabar, Nigeria. Premenstrual syndrome and dysmenorrhea were so severe that they generated a large number of school absences with a percentage of $12.2 \%$, which is similar to reports in India (Ajah et al., 2015).

b. Knowledge

Based on research by (Ajah et al., 2015), it was found that the majority (81.4\%) of the respondents in this study received menstrual education from their mothers, which is similar to the findings of other studies in Nigeria and Ghana.

c. Economy Condition

Research conducted by (Ajah et al., 2015) analyzed that the significance of sexually active students who were more than 15 years old in this study was supported by previous reviews. One of them is by Olalekan, where in his findings it states that urban residents and women are less likely to have sexual intercourse earlier. Early sexual activity, common among children with low socioeconomic parents. This may be because the girls lack the basic necessities of life, necessitating their sexual activity as a means of survival socially and economically. This is supported by an earlier report in South Africa where poor individuals, due to a lack of alternatives to livelihoods, end up engaging in sexual transactions (Ajah et al., 2015)

d. Sexual Desire

Research conducted by (Glynn et al., 2010) states that the age of sexual desire and age at marriage will increase with age at menarche. For example, among people with early menarche ( $<14$ years of age, $60 \%$ were married and only $11 \%$ were not sexually active by 17 years of age, compared with $11 \%$ who were married and $71 \%$ were not sexually active among those with late menarche (ages $\geq 16$ ) 
This is in line with research by (Tey et al., 2019) which states that sexual debut at the age of 15 in women who have their first menstruation before the age of 12 years is 4.4 times greater than those who have menstruation at the age of 14 years.

\section{DISCUSSION}

\section{Sexual and Reproductive Health Problems}

Based on research by (Ajah et al., 2015), currently those who experience early menarche have the possibility of experiencing a risk of premature sexual activity. This is supported by previous reports from the United States. In that study, menarche was characterized by the initiation of female reproductive activity where the onset of menarche led to early coitus activity and early marriage, with complications from the staff in the form of induction for abortion, preeclampsia and eclampsia, obstructed labor, and vesicovaginal fistula. Some of these complications cause maternal morbidity and mortality in young women and are common in adolescents. The adolescent maternal mortality ratio in Sokoto, northwest Nigeria, is 5,415 per 100,000 live births and accounts for more than $23 \%$ of maternal deaths in Abakaliki, southeast Nigeria. Additionally, a significant proportion of students who were sexually active at more than 15 years of age in this study were supported by a previous review by Olalekan, in which urban residents and women may have had baseline coitus. The onset of common sexual activity among children with low socioeconomic parents in this study may be because the girls have a less basic life basis, thus requiring them to use their sexual activity as a means of socioeconomic survival. This is supported by previous reports in South Africa where poor individuals, due to lack of alternatives to livelihoods, end up engaging in sexual transactions.

This study was supported by (Tey et al., 2019) who found that only $7.2 \%$ of those aged 16-20 years are currently using the contraceptive method $29.6 \%$ (13.8\% using pills and $1.5 \%$ use condoms). The low contraceptive prevalence in the Philippines is partly due to religious opposition preventing the implementation of stronger programs to promote the use of modern contraceptives. Therefore, it can be concluded that the majority of Filipino women have unprotected sex during their first sexual intercourse. Sex without a condom creates reproductive health problems, especially sexually transmitted diseases, unwanted pregnancy and abortion, in addition to psychological and emotional stress. Previous studies have found that sexually active adolescents are more likely to use pills or condoms in the first intercourse if they are given contraceptive education.

The sex education curriculum can effectively reduce adolescent sexual risk behavior, early sexual desire and teenage pregnancy (Mueller et al., 2008). The Philippines in this regard may be in the same situation as many other countries where the development of social support and education has not kept pace with the trend of reducing the age of sexual maturity. In order to address adolescent sexual and reproductive health issues and in order to substantially reduce teenage pregnancies, there is a need to equip young people with reproductive health knowledge and promote responsible and healthy lifestyles. This study was supported by (Tey et al., 2019) who found that only $7.2 \%$ of those aged 16-20 years are currently using the contraceptive method $29.6 \%$ (13.8\% using pills and $1.5 \%$ use condoms). The low contraceptive 
prevalence in the Philippines is partly due to religious opposition preventing the implementation of stronger programs to promote the use of modern contraceptives. Therefore, it can be concluded that the majority of Filipino women have unprotected sex during their first sexual intercourse. Sex without a condom creates reproductive health problems, especially sexually transmitted diseases, unwanted pregnancy and abortion, in addition to psychological and emotional stress. Previous studies have found that sexually active adolescents are more likely to use pills or condoms in the first intercourse if they are given contraceptive education.

The sex education curriculum can effectively reduce adolescent sexual risk behavior, early sexual desire and teenage pregnancy (Mueller et al.,2008). The Philippines in this regard may be in the same situation as many other countries where the development of social support and education has not kept pace with the trend of reducing the age of sexual maturity. In order to address adolescent sexual and reproductive health issues and in order to substantially reduce teenage pregnancies, there is a need to equip young people with reproductive health knowledge and promote responsible and healthy lifestyles.

\section{Diseases of sexual and reproductive health}

The association between early menarche and HSV-2 infection arises because of the presence of risky behavior or a higher risk partner and the association with HIV infection may also occur. This is mainly because HSV-2 infection and HIV infection are so closely related to each other. However, it has been shown that HIV is much more prevalent in this population, so that a woman's risk of acquiring HIV depends on herself or her partner's behavior, and more on local prevalence (the probability that a given risky behavior will lead to partner exposure to HIV infection), and on occasion (Glynn et al., 2014)

HIV infection is more common in those with low levels of education, with parents who also have less education than those who live in better-built houses and in those who work with a good economic level. The incidence of HSV-2 infection was similar to those in more remote areas, such as in areas close to roads and not related to parental education or type of housing. It is most common among those with secondary or further education, and among those still in education. It was slightly more common among people reporting food insecurity (Glynn et al., 2014)

\section{Factors Affecting Sexual and Reproductive Health}

Nearly half of the women under the age of 14 had had sexual relations by the age of 16 and were found to be pregnant so that marriage was a reason for leaving school (Glynn et al., 2010). From a survey conducted at an antenatal clinic (ANC) in the same setting, there were $31 \%$ of adolescent women attending ANC with their first pregnancy while still having school education. As many as $8 \%$ of adolescent women attending ANC with subsequent pregnancies had also been at school when they became pregnant, confirming that some of these women were able to return to education after childbirth. For women, menstruation may be a factor affecting their early pregnancy, as well as sexual desire. 
Mothers are a very important resource as well as the preferred choice regarding the provision of education on menstrual issues and emotional support to girls, as many girls are uncomfortable discussing menstruation with their fathers. However, these girls are prone to getting misinformation from their mothers because of the perceived higher illiteracy rate among their mothers when compared to fathers, especially in lower socioeconomic classes, in Nigeria. In this study, experiencing menstruation might be a surprise as $6.2 \%$ of the respondents had never received menstrual education before. The appropriate sources of menstrual education teachers consisting of health institutions, media, and books / magazines are a small part of this research. This shows that education on menstruation still needs to be improved (Ajah et al., 2015).

This analysis found that marital status and education level were the two main determinants of early sexual debut. Efforts made with regard to sexual and reproductive health education should aim to encourage the participation of girls in school, and at the same time prevent teenage marriage. There is also a need to introduce and strengthen sexual and reproductive health education in schools and in informal education, such as through the media and the internet, improve family planning and information services, and involves young people in healthy activities such as sports and community services. A more comprehensive and integrated effort to address the problem of teenage sexuality should be undertaken by involving a wide range of stakeholders, including youth, their parents, teachers, religious leaders, government officials, medical practitioners, non-governmental organizations (NGOs) and the media.

\section{CONCLUSION}

Based on the results of the scoping review from 9 articles, it can be concluded that early menarche has an impact on the occurrence of active sex in students, even sex initiation was found to occur at $<15$ years of age and only eight $(18.6 \%)$ of 43 respondents had ever used modern contraception. and having unprotected sex at age $<16$ years. Furthermore, the effect of early menarche on sexual and reproductive health diseases is the appearance of Herpes simplex type-2 (HSV-2) in women aged <14 years where at that age they had menarche and had sexual intercourse, and 5.6\% were found to be HIV positive. Factors that affect sexual and reproductive health include education, knowledge, economy, sexual desire. Sexual debut in women aged 15 years and having their first menstrual period before the age of 12 was 4.4 times greater than in those who had their first menstruation at age 14.

Early menarche and high sexual desire are public health problems that have serious implications for adolescents. There is a need to provide adolescents with appropriate information and education on sexual and reproductive health. Providing formal and informal school programs with innovative educational approaches including peer counseling for adolescents and orientation for parents is very necessary. There is a need for qualitative research in Indonesia to see to what extent parents or teachers in schools understand about sex education in children considering that parents and teachers are their first places to ask questions. This needs to be done especially in pre-pubertal adolescents to prevent unwanted health problems associated with risky behavior. 


\section{REFERENCES}

Ajah, L. O., Onubogu, E. S., Anozie, O. B., Lawani, L. O., Iyoke, C. A., Onwe, E. O., \& Ajah, M. I. (2015). Adolescent reproductive health challenges among schoolgirls in southeast Nigeria: Role of knowledge of menstrual pattern and contraceptive adherence. Patient Preference and Adherence, 9, 1219-1224. https://doi.org/10.2147/PPA.S89258

Araújo, M. L. D. et al. (2016) 'Early menarche in normal-weight girls and its association with excess weight, abdominal obesity and metabolic changes at the end of sexual maturation', Nature Publishing Group. Nature Publishing Group, (December 2015), pp. 1278-1284. doi: 10.1038/ejen.2016.103.

Arksey, H., \& O’Malley, L. (2005). Scoping studies: Towards a methodological framework. International Journal of Social Research Methodology: Theory and Practice, 8(1), 19-32. https://doi.org/10.1080/1364557032000119616

Belsky, J., Steinberg, L., Houts, R. M., Halpern-Felsher, B. L., \& the NICHD Early Child Care Research Network. (2010). The Development of Reproductive Strategy in Females: Early Maternal Harshness $\rightarrow$ Earlier Menarche $\rightarrow$ Increased Sexual Risk Taking. Developmental Psychology, 46(1), 120-128. https://doi.org/10.1037/a0015549

Downing, J., \& Bellis, M. A. (2009). Early pubertal onset and its relationship with sexual risk taking, substance use and anti-social behaviour: a preliminary cross-sectional study. BMC Public Health, 9, 446. https://doi.org/10.1186/1471-2458-9-446

Darmayitasari, R. (2017). Gambaran Kejadian Menarche Dini pada Siswi SD Muhammadiyah Wirobrajan 3 Kota Yogyakarta. Karya Tulis Ilmiah. Program Studi Kebidanan. STIKes Jendral Achmad Yani Yogyakarta

Fildza, et al. (2014). Analisis Faktor yang Berhubungan dengan Kejadian Menarche pada Siswi di SMP Swasta Harapan 1 dan 2 Medan. Skripsi. Departemen Epidemiologi. FKM USU Medan

Ganabathy, et al. (2016). Age Pattern at Menarche as Results From A Puberty Survey. Althea Medical Journal. 3 (4). 640-643

Gaudineau, A., Ehlinger, V., Vayssiere, C., Jouret, B., Arnaud, C., \& Godeau, E. (2010). Factors associated with early menarche: results from the French Health Behaviour in School-aged Children (HBSC) study. BMC Public Health, 10, 175. https://doi.org/10.1186/1471-2458-10-175

Glynn, J. R., Kayuni, N., Floyd, S., Banda, E., Francis-Chizororo, M., Tanton, C., ... French, N. (2010). Age at menarche, schooling, and sexual debut in northern Malawi. PloS One, 5(12), e15334. https://doi.org/10.1371/journal.pone.0015334

Glynn, J. R., Kayuni, N., Gondwe, L., Price, A. J., \& Crampin, A. C. (2014). Earlier menarche is associated with a higher prevalence of Herpes simplex type-2 (HSV-2) in young women in rural Malawi. ELife, 3, e01604. 
https://doi.org/10.7554/eLife.01604

Kusmiran, Eny. (2014). Kesehatan Reproduksi Remaja dan Wanita. Jakarta: Salemba Medika.

Marino, J. L., Skinner, S. R., Doherty, D. A., Rosenthal, S. L., Cooper Robbins, S. C., Cannon, J., \& Hickey, M. (2013). Age at menarche and age at first sexual intercourse: A prospective cohort study. Pediatrics, 132(6), 1028-1036. https://doi.org/10.1542/peds.2012-3634

Mendle, J., Ryan, R. M., \& McKone, K. M. P. (2019). Early Menarche and Internalizing and Externalizing in Adulthood: Explaining the Persistence of Effects. The Journal Of Adolescent Health: Official Publication Of The Society For Adolescent Medicine, 65(5), 599-606. https://doi.org/10.1016/j.jadohealth.2019.06.004

Mueller, T. E., Gavin, L. E., \& Kulkarni, A. (2008). The Association Between Sex Education and Youth's Engagement in Sexual Intercourse, Age at First Intercourse, and Birth Control Use at First Sex. Journal of Adolescent Health, 42(1), 89-96. https://doi.org/10.1016/j.jadohealth.2007.08.002

Platt, et al. (2017). Transdiagnostic Psychiatric Disorder Risk Associated with Early Age of Menarche: A Latent Modeling Approach. Comprehensive Psychiatry. 79 (3). 7079

Susanti, Agnes Vivi. (2012). Faktor Risiko Kejadian Menarche Dini pada Remaja di SMP N 30 Semarang. Skripsi. Fakultas Kedokteran. Universitas Diponegoro.

Tey, N.-P., Lai, S.-L., \& Ng, S.-T. (2019). Age At Menarche And Sexual Debut Among Young Filipino Women. Journal Of Biosocial Science, 51(1), 77-94. https://doi.org/10.1017/S0021932017000682

Tricco, A. C., Lillie, E., Zarin, W., O’Brien, K., Colquhoun, H., Kastner, M., ... Straus, S. E. (2016). A scoping review on the conduct and reporting of scoping reviews. BMC Medical Research Methodology, 16(1), 1-10. https://doi.org/10.1186/s12874-016-0116-4 